Article

\title{
Winter Thermal Environment and Thermal Performance of Rural Elderly Housing in Severe Cold Regions of China
}

\author{
Huibo Zhang ${ }^{1, *(\mathbb{D},}$, Ya Chen ${ }^{2}$, Hiroshi Yoshino ${ }^{3}$, Jingchao Xie ${ }^{4}$, Zhendong Mao ${ }^{2}$, Jingwen Rui ${ }^{2}$ \\ and Jinfeng Zhang ${ }^{5}$ \\ 1 Department of Architecture, School of Design, Shanghai Jiao Tong University, Shanghai 200240, China \\ 2 China-UK Low Carbon College, Shanghai Jiao Tong University, Shanghai 200240, China; \\ madilyn@sjtu.edu.cn (Y.C.); tobeamiracle@sjtu.edu.cn (Z.M.); ruijingwen@sjtu.edu.cn (J.R.) \\ 3 Yangtze Delta Region Institute of Tsinghua University, Jiaxing 314006, China; \\ yoshino@sabine.pln.archi.tohoku.ac.jp \\ 4 College of Architecture and Civil Engineering, Beijing University of Technology, Beijing 100000, China; \\ xiejc@bjut.edu.cn \\ 5 Longjiang Jing Xi Machinery Manufacturing Co., Ltd., Qigihar 161100, China; z18746299988@163.com \\ * Correspondence: zhanghuibo@sjtu.edu.cn; Tel.: +86-13818784711
}

Received: 21 April 2020; Accepted: 28 May 2020; Published: 3 June 2020

\begin{abstract}
Understanding the thermal performance of the residential envelope is important for optimizing the indoor thermal environment. In this study, the indoor thermal environment and thermal performance of rural residences housing the elderly was determined through field measurements in Qiqihar in 2017 and 2019. The results revealed that the living room temperatures in more than $50 \%$ of homes were below the thermal neutral temperature for the elderly $\left(17.32{ }^{\circ} \mathrm{C}\right)$. Moreover, the indoor thermal environment changed significantly during the day, with the predicted mean vote during the day fluctuating from 2 to 4 units. The air change rate of living rooms in 2017 and 2019 was $0.20-2.20 \mathrm{~h}^{-1}$ and $0.15-1.74 \mathrm{~h}^{-1}$, respectively. Residential ventilation times detected by an air-tightness detector ranged from $0.40-1.49 \mathrm{~h}^{-1}$. Furthermore, infrared thermography (IRT) detected air leakage in the windows of the all houses in this study, as well as thermal bridges and condensation on the exterior walls of several houses. The heat transfer coefficient of the exterior walls of all houses detected by IRT was $0.25-0.74 \mathrm{~W} /\left(\mathrm{m}^{2} \cdot \mathrm{K}\right)$, and a significant positive correlation was observed between the heat transfer coefficient of the south wall and the window-to-wall ratio. Finally, the heat transfer coefficient of the external walls exhibited a negative but not significant correlation with indoor temperature. This study provides detailed data and guidance for improving the indoor environment of rural houses in severe cold regions.
\end{abstract}

Keywords: severe cold region; rural elderly housing; thermal environment; airtightness; thermal performance

\section{Introduction}

In recent years, urbanization has developed rapidly in China; however, $40 \%$ of the population still lives in rural areas [1]. Moreover, with a continued increase in the proportion of rural residents over 65, the age structure of this rural population has become dominated by the elderly (over 61 years old), who are now the main force of rural production [2]. In addition, China's urban and rural development is unequal; in severe cold regions, urban residences are provided with centralized heating, whereas rural residences still adopt a decentralized heating method [3,4]. Research comparing elderly people living in urban and rural residences has shown that rural elderly people live in an environment where the 
room temperature is lower and a large temperature gradient exists between the indoors and outdoors, which affects their health and thermal comfort [5]. Numerous international studies have analyzed the health of the elderly living in cold environments and reported that a low temperature environment leads to cardiovascular and cerebrovascular diseases [6-8]. Therefore, as centralized heating is not attainable in rural areas, it is necessary to analyze heating types and the thermal performance of the residential envelope in China in order to determine the current status of indoor thermal environments and achieve a more comfortable indoor thermal environment for rural elderly housing.

Some previous studies have analyzed the rural indoor thermal environment in severe cold regions in China. Ma et al. conducted a thermal comfort survey in rural dwellings in the southern region of Liaoning Province and found that residents in this area had lower temperature requirements [9]. In a field study of the thermal environment of Beijing's urban and rural elderly in cold areas, Fan revealed that the indoor temperature of rural houses was $14.6-16.1^{\circ} \mathrm{C}$ and the elderly had a higher acceptance of the indoor thermal environment [10]. However, few studies have conducted in-depth analyses of the thermal performance of the rural residential envelope structure, which is an important factor affecting the indoor thermal environment.

Poor thermal performance of the residential envelope structure is reflected in poor insulation performance and the severe infiltration of cold air, which leads to massive energy consumption $[11,12]$. Many scholars have attempted to optimize the thermal design of the residential envelope structures to save energy and achieve comfortable indoor environments. Shao believed that the south window-to-wall ratio was the most important factor affecting the indoor temperature of rural dwellings in cold areas in the northern hemisphere, and proposed an ideal ratio of $45 \%$ [13]. Zhu and Liu revealed the importance of external wall thickness for energy saving in Yaodong dwellings (traditional earth shelter dwellings in the Loess Plateau); that is, increasing the wall thickness can create a more comfortable indoor thermal environment [14]. Li applied reform measures to the envelope structure of rural houses according to energy-saving design standards, which increased the energy-saving rate of renovated houses to $62.6 \%$ and raised the indoor room temperature by about $3{ }^{\circ} \mathrm{C}$ [15]. These studies optimized the thermal performance of a house from a passive design perspective at a low cost; however, they typically only focused on one or more aspects of thermal performance, such as the thickness of the external wall or the window-to-wall ratio, without analyzing the overall thermal performance of the house through the residential heat transfer coefficient or air tightness of the exterior wall.

The purpose of this study was therefore to analyze the indoor thermal environment and performance of rural elderly housing in the severe cold regions of China. The rural area of Jingxing Town, Qiqihar, was used as a case study. The thermal environment of typical rural elderly housing in this area was measured during the winters of 2017 and 2019. The thermal coefficient was measured and theoretically calculated and the relationship between the residential thermal environment and the heating intensity and thermal performance of the envelope structure was analyzed. This study aimed to provide guidance for optimizing the indoor thermal environment of rural elderly housing in this climatic zone.

\section{Methodology}

\subsection{Research Site and Objects}

Qiqihar is located in the severe cold area of Northeast China at an altitude between 140 and $400 \mathrm{~m}$. The average temperature of the coldest month in winter is below $-20^{\circ} \mathrm{C}$. Field measurements were conducted on ten and eight residences from 14 to 21 January 2017 and from 16 to 24 January 2019, respectively (Figures 1 and 2). Four residences were involved in the two-year measurement (R1/Q1, R2/Q2, R3/Q3, and R4/Q4). Table 1 shows the basic information of the measured households. The average residential area was $56.6 \mathrm{~m}^{2}$ and more than $50 \%$ of the buildings were over 20 years old. Except for R3/Q3, which only adopted a "Chinese Kang" as heating equipment during cooking times and bedtime, the residences utilized both a "Chinese Kang" and radiators during cooking times and 
bedtime. For the Chinese Kang (Figure 3a), the coal or firewood was burned in the cooking bench from the fuel inlet during cooking; the resulting hot flue gas passed to the chamber beneath the Kang. Subsequently, the Kang was heated by convective heat transfer from the hot flue gas. Finally, the heat diffused indoors through the Kang surface. Alternatively, the heating stove (Figure $3 b$ ) was installed in the kitchen and connected to the bedroom radiator through metal pipes. The water in the pipes was heated by the stove and subsequently circulated by gravity. There were no thermostats on the heating equipment; indoor temperatures could be increased by adding fuel to the stove when the residents felt cold. R2/Q2 operated heating equipment throughout the day. In addition, all the houses were built using brick walls as the main load-bearing structure of the external wall, with houses R1/Q1, R2/Q2, $\mathrm{R} 3 / \mathrm{Q} 3$, and $\mathrm{R} 4 / \mathrm{Q} 4$ using thermal insulation materials in the exterior walls.

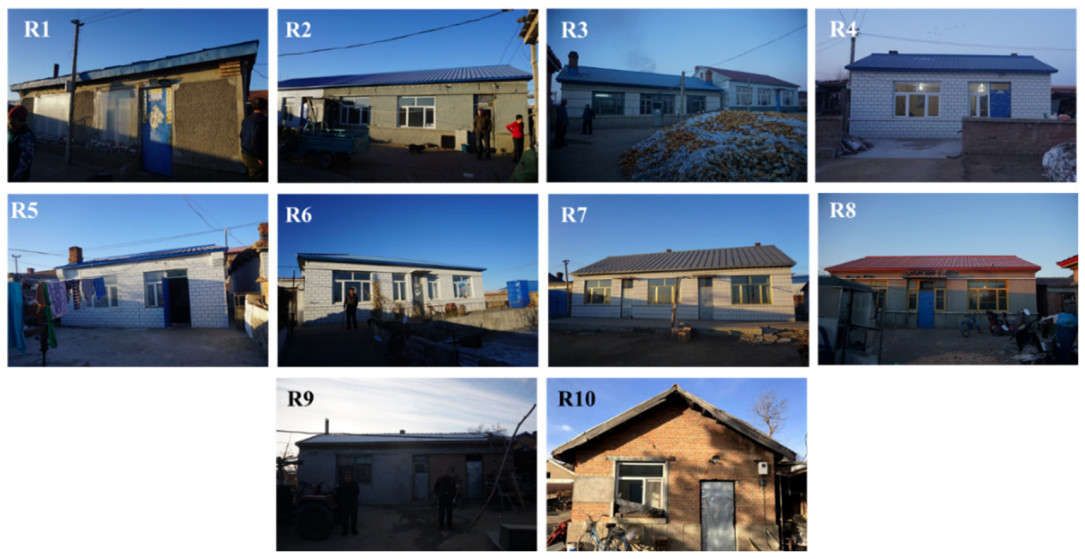

Figure 1. Photographs of the ten houses used for the field measurements in January 2017.
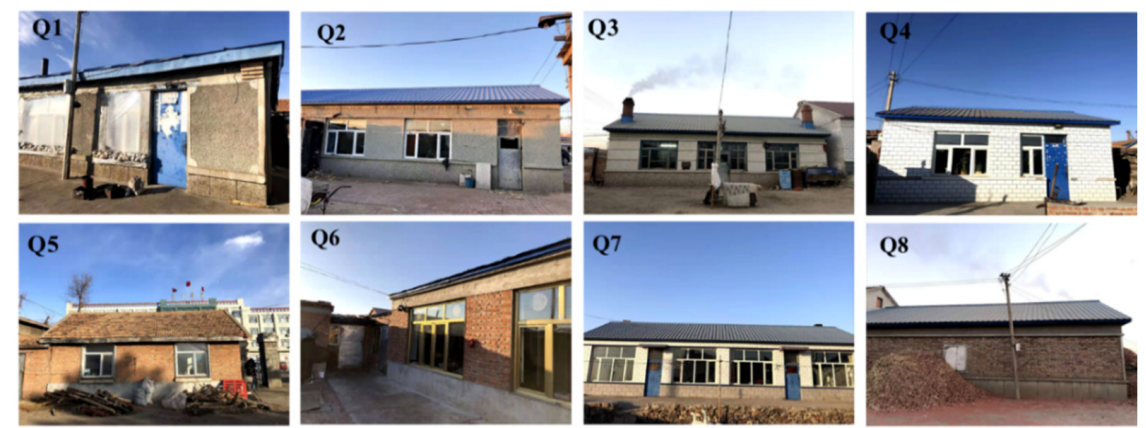

Figure 2. Photographs of the eight houses used for the field measurements in January 2019.
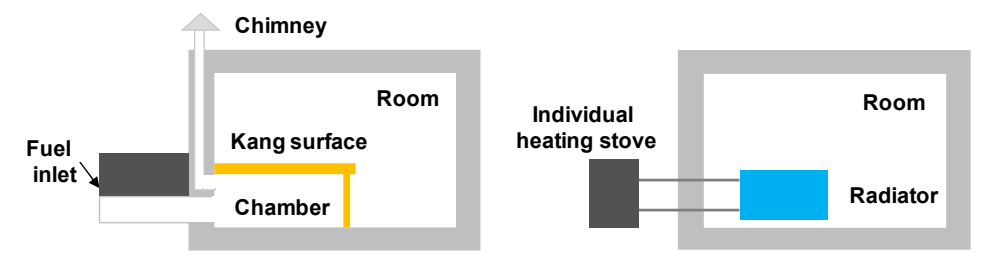

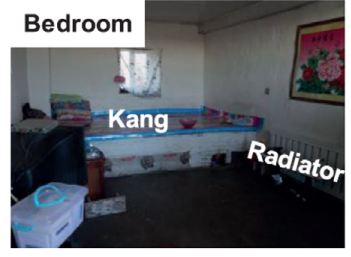

(a)

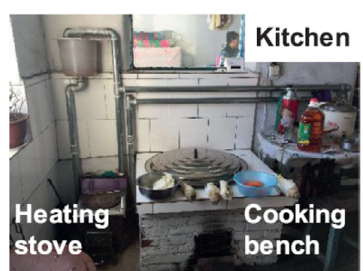

(b)

Figure 3. Typical heating system structures in the rural houses. (a) Chinese Kang; (b) Heating stove. 
Table 1. Basic information of the measured residences.

\begin{tabular}{|c|c|c|c|c|c|c|c|}
\hline Housing ID & $\begin{array}{l}\text { Building } \\
\text { Height }[\mathrm{m}]\end{array}$ & Orientation & $\begin{array}{l}\text { Housing } \\
\text { Area }\left[\mathrm{m}^{2}\right]\end{array}$ & $\begin{array}{l}\text { Housing } \\
\text { Age [years] }\end{array}$ & $\begin{array}{l}\text { "Chinese Kang" + } \\
\text { Radiator [Y/N] }\end{array}$ & Duration of Heating & $\begin{array}{c}\text { Insulation Materials } \\
\text { on External Wall [Y/N] }\end{array}$ \\
\hline R1/Q1 & 2.52 & South & 68 & $>20$ & $\mathrm{Y}$ & Breakfast, dinner-bedtime & $\mathrm{N}$ \\
\hline $\mathrm{R} 2 / \mathrm{Q} 2$ & 2.54 & South & 70 & $>20$ & $\mathrm{Y}$ & All day & $\mathrm{N}$ \\
\hline $\mathrm{R} 3 / \mathrm{Q} 3$ & 2.42 & South & 65 & $>20$ & N (only Chinese Kang) & Breakfast, dinner-bedtime & $\mathrm{N}$ \\
\hline $\mathrm{R} 4 / \mathrm{Q} 4$ & 2.27 & South & 86 & $>20$ & Y & Breakfast, dinner-bedtime & $\mathrm{Y}$ \\
\hline R5 & 2.8 & East & 50 & $5-10$ & $\mathrm{Y}$ & No answer & $\mathrm{N}$ \\
\hline R6 & 2.8 & South & 96 & $10-20$ & Y & Breakfast, dinner-bedtime & $\mathrm{Y}$ \\
\hline R7 & 2.8 & South & 32 & $3-5$ & $\mathrm{Y}$ & Breakfast, dinner & $\mathrm{N}$ \\
\hline R8 & 2.8 & South & 55 & $>20$ & $\mathrm{Y}$ & Waking-bedtime & $\mathrm{Y}$ \\
\hline R9 & 2.8 & South & 71 & $10-20$ & $\mathrm{Y}$ & Breakfast, dinner-bedtime & $\mathrm{N}$ \\
\hline R10 & 2.8 & South & 40 & $>20$ & $\mathrm{Y}$ & No answer & $\mathrm{Y}$ \\
\hline Q5 & 2.42 & South & 30 & $3-5$ & $\mathrm{Y}$ & Breakfast, dinner-bedtime & $\mathrm{N}$ \\
\hline Q6 & 2.33 & South & 40 & $>20$ & $\mathrm{Y}$ & Waking-bedtime & $\mathrm{N}$ \\
\hline Q7 & 2.82 & South & 50 & $10-20$ & $\mathrm{Y}$ & Breakfast, dinner-bedtime & $\mathrm{N}$ \\
\hline $\mathrm{Q} 8$ & 2.36 & South & 39 & $>20$ & Y & Breakfast, dinner-bedtime & $\mathrm{N}$ \\
\hline
\end{tabular}




\subsection{Measurement of the Residential Thermal Environment}

\subsubsection{Temperature and Relative Humidity}

The indoor and outdoor temperature and relative humidity $(\mathrm{RH})$ of the residences were monitored continuously. A thermo-hygrometer T\&D 76U: (measurement accuracy: $\pm 0.5{ }^{\circ} \mathrm{C}, \pm 5 \% \mathrm{RH}, \pm 50 \mathrm{ppm}$ ) was used for the temperature and $\mathrm{RH}$ detection.

\subsubsection{Predicted Mean Vote (PMV)}

The predicted mean vote (PMV), which indicates the mean comfort response of a group of occupants on the seven-point ASHRAE (American Society of Heating, Refrigerating and Air-Conditioning Engineers) thermal sensation scale (from +3 to -3 ), was monitored continuously for $24 \mathrm{~h}$ in the living room using a Testo 480 multifunction meter. Monitoring parameters included the mean radiated temperature (MRT) $\left(0-120^{\circ} \mathrm{C}, \pm 0.5^{\circ} \mathrm{C}\right)$, air temperature $\left(-20-70{ }^{\circ} \mathrm{C}, \pm 0.2{ }^{\circ} \mathrm{C}\right), \mathrm{RH}(0-100 \%, \pm 1.0 \%)$, and wind speed $(0-20 \mathrm{~m} / \mathrm{s}, \pm 0.03 \mathrm{~m} / \mathrm{s})$. Due to the limitations of the research conditions, this study only continuously monitored the PMV of four residential living rooms (Q2, Q4, Q5, Q7) in January 2019. In order to avoid the influence of solar radiation, the PMV monitoring instrument was placed as close to the middle of the room as possible, as shown in Figure 4.

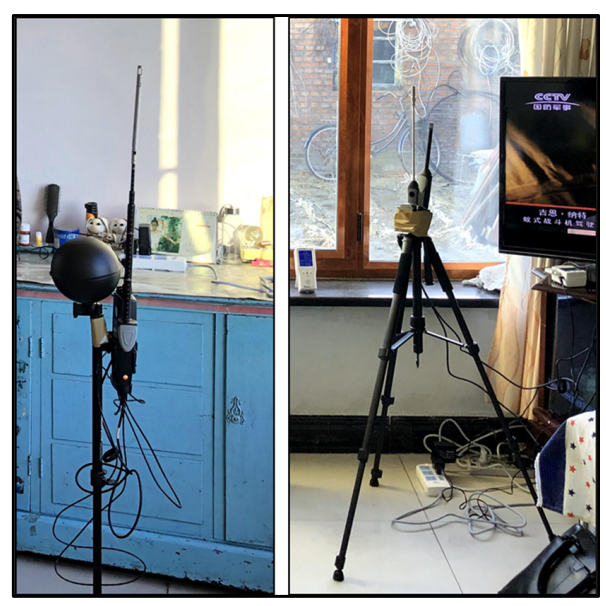

Figure 4. Predicted mean vote (PMV) detection equipment in a living room.

The calculation of the PMV by the Testo 480 multifunctional measuring instrument was based on the thermal comfort equation proposed by Fanger [16]:

$$
\begin{gathered}
\text { PMV }=[0.303 \exp (-0.036 \mathrm{M})+0.028] \mathrm{L} \\
L=(M-W)-3.05 \times 10^{-3}\left[5.733-6.99(M-W)-p_{a}\right]-0.42[(M-W)-58.15] \\
-1.7 \times 10^{-5} M\left(5.867-p_{a}\right)-0.0014 M\left(34-t_{a}\right) \\
-3.96 \times 10^{-8} f_{c l}\left[\left(t_{c l}+273\right)^{4}-\left(t_{r}+273\right)^{4}\right]-f_{c l} h_{c}\left(t_{c l}-t_{a}\right)
\end{gathered}
$$

where $\mathrm{M}$ is the metabolic rate $\left(\mathrm{W} / \mathrm{m}^{2}\right) ; \mathrm{W}$ is the useful work $\left(\mathrm{W} / \mathrm{m}^{2}\right) ; p_{a}$ is the partial pressure of the water vapor $(\mathrm{Pa})$, which is related to $\mathrm{RH} ; t_{a}$ is the air temperature $\left({ }^{\circ} \mathrm{C}\right) ; f_{c l}$ is the dressing area coefficient determined by the clothing thermal resistance $\left(\mathrm{I}_{\mathrm{cl}}\right) ; t_{c l}$ is the surface temperature of clothing $\left({ }^{\circ} \mathrm{C}\right) ; t_{r}$ is the average radiant temperature $\left({ }^{\circ} \mathrm{C}\right)$; and $h_{c}$ is the convective heat transfer coefficient $\left(\mathrm{W} /\left(\mathrm{m}^{2}{ }^{\circ} \mathrm{C}\right)\right)$.

For the parameters in formula (2), only the metabolic rate and clothing thermal resistance need to be manually input; the temperature, humidity and wind speed probes connected to the Testo 480 can detect all the other parameters. For the metabolic rate, ISO7730 recommends a metabolic rate for a sedentary 30-year-old adult of $69.8 \mathrm{~W} / \mathrm{m}^{2}$ [17]. Considering that the metabolic rate of elderly people is relatively low, a value of $64 \mathrm{~W} / \mathrm{m}^{2}$ was used in this study [3]. In addition, related research has reported 
an average indoor clothing thermal resistance of elderly rural residents in this region of 1.28 clo [3]. These known parameters were employed to continuously compute the indoor PMV.

\subsection{Measurement of the Thermal Performance of Residential Envelope Structures}

\subsubsection{Residential Air Tightness}

The residential air tightness was expressed as the air change rate $(\mathrm{ACH})$ of the house between the standard state (at a pressure difference of $50 \mathrm{~Pa}, \mathrm{ACH}_{50}$ ) and the natural state $(\mathrm{ACH}) . \mathrm{ACH}_{50}$ assumes that the doors and windows of the house are tightly closed to ensure a specific pressure difference. The leakage air volume under this pressure difference was used to obtain the leakage air volume and the gap area of the house at $50 \mathrm{~Pa}$ in the standard air state in order to calculate the residential ventilation rate in the natural state; i.e., $\mathrm{ACH}=\mathrm{ACH}_{50} / 17$ [18]. Due to the limitation of the detection conditions, the air-tightness tests were only performed in five households in 2019 (Q2, Q4, Q6, Q7, Q8). A Dr. Dolphin (made in Japan) device was used to conduct the air-tightness test. In this study, the air tightness of a house was measured using the decompression method specified in the ASTM (American Society for Testing and Materials) E779 standard [19]. The detection steps were as follows. First, the blower was started to ensure a pressure difference of approximately $100 \mathrm{~Pa}$ between the indoors and outdoors, then the air volume and pressure difference were recorded, and the indoor and outdoor pressure difference were reduced from high to low, adjusted six times, and the data was recorded until the indoor and outdoor pressure difference was approximately $10 \mathrm{~Pa}$. The test environment is shown in Figure 5.

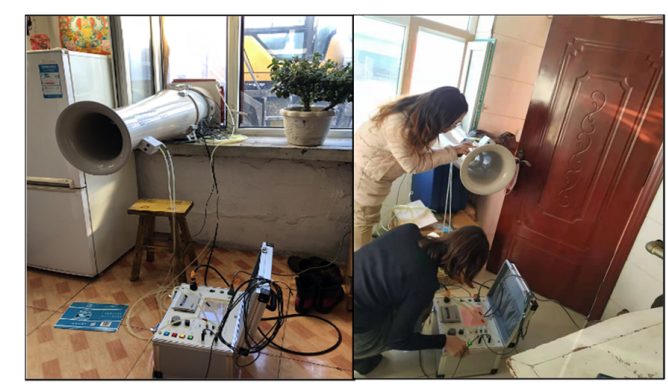

Figure 5. Residential air-tightness test environment.

\subsubsection{Residential Envelope Thermal Defects and Heat Transfer Coefficients of External Walls}

Infrared thermography (IRT) technology is widely used to detect the thermal performance of the building envelope. IRT is a non-destructive imaging technology used to visualize the infrared radiation emitted from the building surface. The thermal image captured by the IRT reveals surface defects in the measured object, such as moisture problems and air leakage around the walls or windows. At present, both the qualitative and quantitative analysis methods are used to analyze IRT results. The qualitative method is used to detect the thermal defects of the residential envelope [20,21], whereas quantitative analysis methods calculate the heat transfer coefficients of the walls and other envelope structures [21-24].

IRT must be performed under specific climatic conditions. The British Thermal Imaging Association provide the following restrictions on the use of IRT: (1) the wind speed around the measured building should be less than $5 \mathrm{~m} / \mathrm{s}$; (2) the indoor and outdoor temperature difference should be at least $10^{\circ} \mathrm{C}$; (3) during the measurement and for a few hours prior, the surface of the building should not be directly exposed to sunlight; and (4) in order to avoid sunlight exposure on sunny days, detection should be conducted on a cloudy day or at night [25]. In order to meet the above conditions, thermal imaging pictures were acquired in the evening. In this study, a FILR T46 thermal imager (infrared resolution: $320 \times 240$ pixels, temperature range: $-20-120^{\circ} \mathrm{C}$, accuracy: $\pm 1{ }^{\circ} \mathrm{C}$ or $\pm 2 \%$ of reading) was employed to detect the residential envelope thermal defects and the heat transfer coefficients of the external walls. 


\section{Results and Discussion}

\subsection{Indoor Thermal Environment}

\subsubsection{Average Air Temperature, $\mathrm{RH}$ and Moisture Ratio}

Figure 6 shows the air temperature, $\mathrm{RH}$ and the moisture ratio of the measured households. A previous study showed that the indoor thermal neutral temperature for elderly people in the area was $17.32{ }^{\circ} \mathrm{C}$ [26]. In this study, $70 \%$ and $50 \%$ of the average living room temperatures were below $17.32{ }^{\circ} \mathrm{C}$ in 2017 and 2019, respectively, and the average kitchen temperatures in all the households were less than $17.32{ }^{\circ} \mathrm{C}$. The indoor temperature of $\mathrm{R} 4$ increased from $9{ }^{\circ} \mathrm{C}$ in 2017 to $18{ }^{\circ} \mathrm{C}$ in 2019 because the flue gas channel of the household was enlarged and renovated to improve the heating efficiency. The RH in the living rooms of five residences met the Chinese standard of GB/T 18883-2002 in both 2017 and 2019; i.e., 30\%-60\% [27]. The moisture ratios in the bedroom, kitchen and outdoors in 2017 were $4.11 \pm 0.24 \mathrm{~g} / \mathrm{kg}$ dry air, $3.85 \pm 0.52 \mathrm{~g} / \mathrm{kg}$ dry air, and $0.37 \pm 0.11 \mathrm{~g} / \mathrm{kg}$ dry air, respectively, whereas those in 2019 were $4.05 \pm 0.29 \mathrm{~g} / \mathrm{kg}$ dry air, $3.36 \pm 0.53 \mathrm{~g} / \mathrm{kg}$ dry air, and $0.56 \pm 0.14 \mathrm{~g} / \mathrm{kg}$ dry air; which were lower than the limitations of the indoor comfort environment: $12 \mathrm{~g} / \mathrm{kg}$ dry air. Therefore, most elderly people in this area are living in indoor environments with poor thermal comfort.

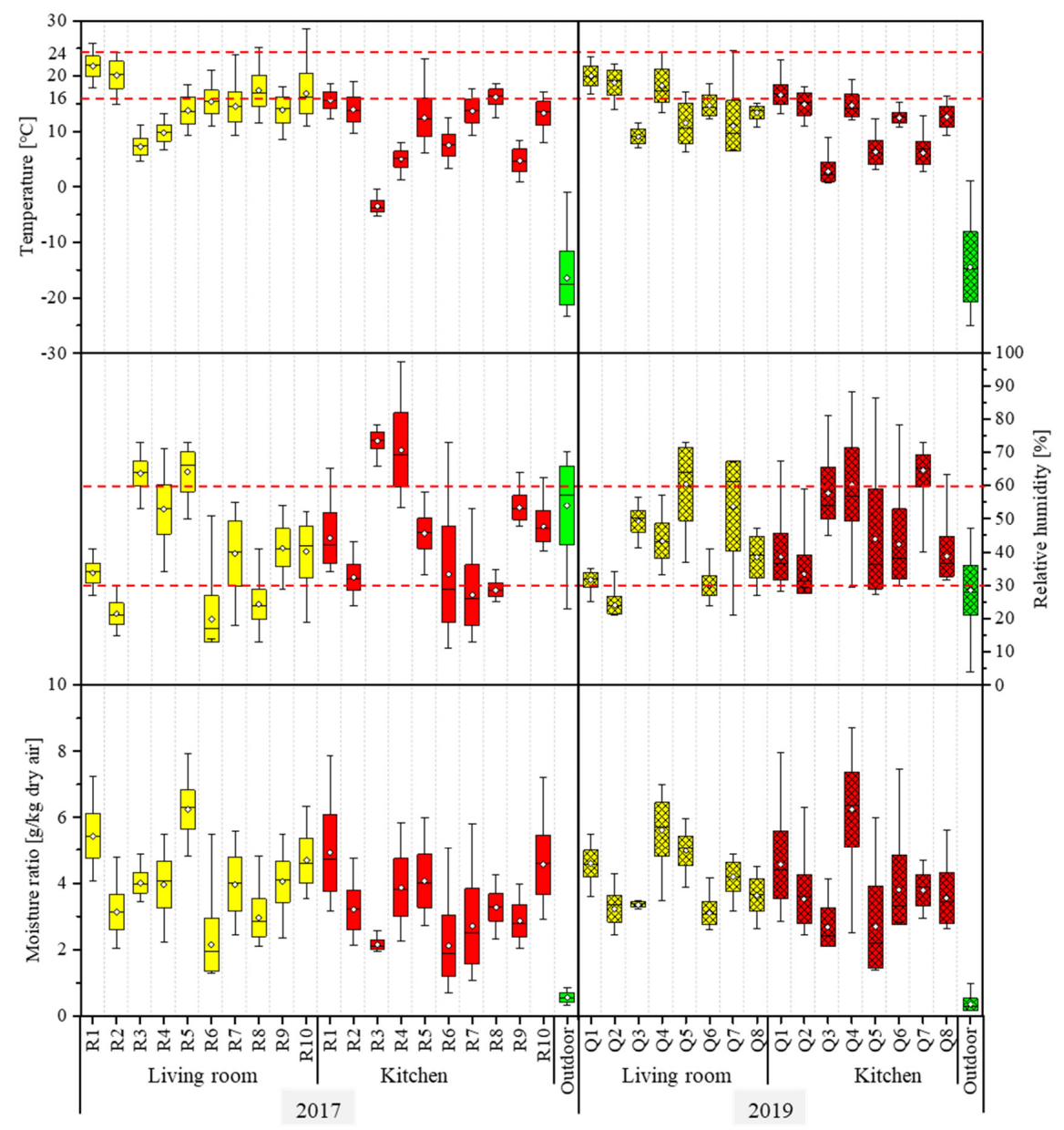

Figure 6. Statistical box of plots of the air temperature, relative humidity $(\mathrm{RH})$ and the moisture ratio in all the measured houses in 2017 and 2019 (the box edges represent the 25th and 75th percentiles, the whiskers represent the 1st and 99th percentiles, the lines in the boxes represent the median values, the symbols represent the mean values and the red dashed lines represent the reference values given by GB/T18883-2002 [27]). 
Table 2 compares the average temperature and $\mathrm{RH}$ of households between the two years. The outdoor temperature difference between 2017 and 2019 was $2{ }^{\circ} \mathrm{C}$, and the temperature difference between the living room and the kitchen was $0.46^{\circ} \mathrm{C}$ and $-0.89^{\circ} \mathrm{C}$ in 2017 and 2019 , respectively. The outdoor RH difference between the two years was $24 \%$, and the RH difference between the living rooms and kitchens was $-1.3 \%$ and $-1.12 \%$ in 2017 and 2019, respectively. Consequently, although the temperature and $\mathrm{RH}$ differences between the indoor and outdoor areas over the two-year measurement period were large, the indoor temperature and $\mathrm{RH}$ differences between the rooms were within $1{ }^{\circ} \mathrm{C}$ and $2 \%$, respectively, indicating that the elderly residents had similar indoor thermal environments over the two-year period.

Table 2. Average indoor temperature and the RH values for the measured houses.

\begin{tabular}{cccccc}
\hline \multirow{2}{*}{ Parameter } & \multirow{2}{*}{ Room } & \multicolumn{2}{c}{$\mathbf{2 0 1 7}$} & \multicolumn{2}{c}{$\mathbf{2 0 1 9}$} \\
\cline { 3 - 6 } & & $\mathbf{N}$ & Average \pm SD & N & Average \pm SD \\
\hline \multirow{2}{*}{ Temperature $\left({ }^{\circ} \mathrm{C}\right)$} & Living room & 10 & $15.06 \pm 1.81$ & 8 & $14.60 \pm 1.64$ \\
& Kitchen & 10 & $9.93 \pm 1.46$ & 8 & $10.82 \pm 1.19$ \\
& Outdoor/Toilet & 10 & $-16.43 \pm 4.90$ & 8 & $-14.38 \pm 5.59$ \\
\hline \multirow{2}{*}{ RH $(\%)$} & Living room & 10 & $40.04 \pm 2.91$ & 8 & $41.34 \pm 3.85$ \\
& Kitchen & 10 & $46.23 \pm 4.41$ & 8 & $47.35 \pm 5.09$ \\
& Outdoor/Toilet & 10 & $53.93 \pm 11.84$ & 8 & $29.96 \pm 7.08$ \\
\hline
\end{tabular}

\subsubsection{Diurnal Variations of the Average Indoor MRT and Air Temperature}

Figure 7 shows the changes in the average MRT and air temperature of four households over $24 \mathrm{~h}$. Among them, Q2, Q4 and Q7 had south-facing windows and the living rooms received direct sunlight in the middle of the day, whereas Q5 had a west-facing window and the room did not receive direct sunlight. Over the midday period (11:00-15:00), the average MRT in the three south-facing households was higher than the air temperature. Over the entire day, the average MRT was higher than the air temperature in Q4, but lower than the air temperature in the Q5 living room. The average MRT of $\mathrm{Q} 2, \mathrm{Q} 5$ and $\mathrm{Q} 7$ was lower than the air temperature $\left(2.5^{\circ} \mathrm{C}, 1.4^{\circ} \mathrm{C}\right.$ and $1.4^{\circ} \mathrm{C}$, respectively), whereas that in $\mathrm{Q} 4$ was $0.6^{\circ} \mathrm{C}$ higher than the air temperature. The indoor MRT is typically lower than the air temperature in winter. Sheng conducted field measurements of the MRT of rural houses in severe cold areas, and revealed that the residential MRT was $2{ }^{\circ} \mathrm{C}-5^{\circ} \mathrm{C}$ lower than the air temperature [28]. For Q4, the thermal radiation from the "Chinese Kang" was increased due to the expansion of the fire channel of the Kang, which may explain why the MRT was higher than the air temperature.

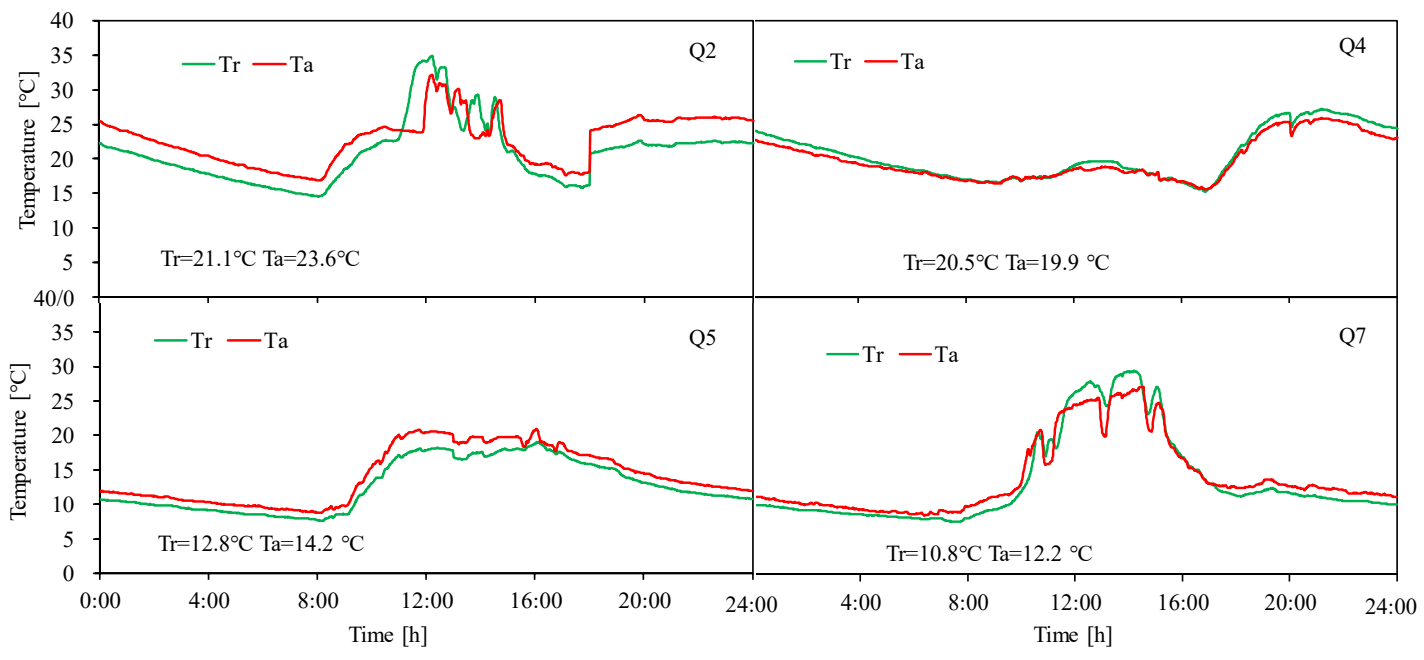

Figure 7. Trends of air temperature and mean radiated temperature (MRT) over $24 \mathrm{~h}$ (Ta: air temperature, Tr: MRT). 


\subsubsection{Diurnal Variations of PMV}

Figure 8 presents the fluctuations of PMV in the living rooms of four houses over a $24 \mathrm{~h}$ period, which ranged from 2 to 4 PMV units. Q2 exhibited a comfortable thermal range (PMV > 0.5) in the middle of the day (09:00-14:00) and at night (18:00-00:00); however, it exhibited a cold environment for the remaining hours. Q4 was in a comfortable range from 12:00-15:00 and Q7 was in a comfortable range at night (18:00-00:00). However, the indoor PMV of Q5 was less than -0.5 all day. Q2, Q4, Q5 and Q7 were cold for $38 \%, 57 \%, 100 \%$ and $83 \%$ of the day, respectively. These results can be explained by the heating duration and orientation of the outer window. Table 1 revealed that Q2 was heated throughout the day, whereas the other three households were only heated during breakfast and from dinner to bedtime. As the living room of Q5 faced west, the room was exposed to minimal sunlight and therefore exhibited lower thermal comfort.

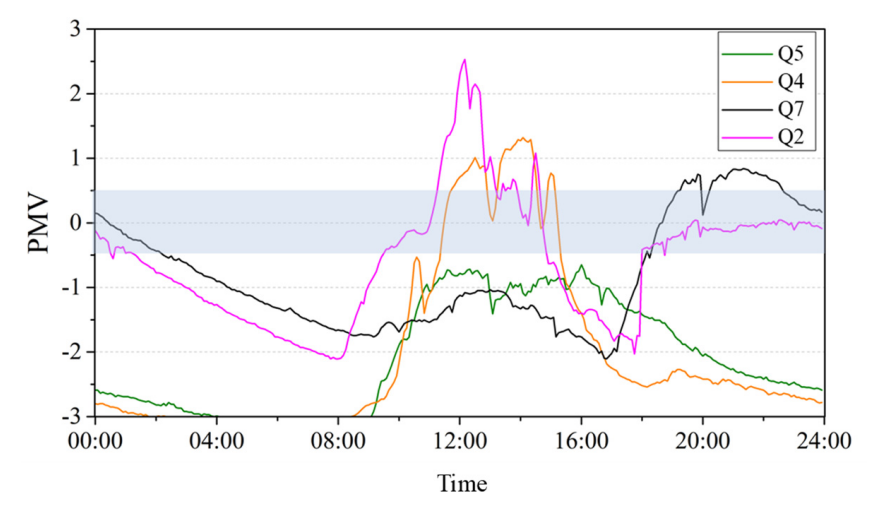

Figure 8. Diurnal variations in the PMV for the living rooms of elderly housing.

\subsection{Thermal Performance of the Residential Envelope}

\subsubsection{Residential Air Tightness}

(1) $\mathrm{CO}_{2}$ gas tracer method for calculating the $\mathrm{ACH}$

The $\mathrm{ACH}$ of the elderly living room was calculated based on the quantitative generation method of $\mathrm{CO}_{2}$ in a room at night $[29,30]$. The results are shown in Table 3. The ACH of the living rooms in 2017 and 2019 was $0.20-2.20 \mathrm{~h}^{-1}$ and $0.15-1.74 \mathrm{~h}^{-1}$, respectively. The design code for the heating ventilation and air conditioning of civil buildings (GB/T 50736-2012) recommends that the residential $\mathrm{ACH}$ should be less than $0.5 \mathrm{~h}^{-1}$ for a residence in severe cold areas with a per capita living area of 20-50 $\mathrm{m}^{2}$ [31]. Among the 10 households measured in 2017, the living room ACH of R3, R4, R5 and R7 met the GB/T 50736-2012 standard. In 2019, three (Q4, Q5 and Q7) of the households exhibited a living room ACH that met the standard. The ACH of R2 (Q2) was $1.62 \mathrm{~h}^{-1}$ and $1.74 \mathrm{~h}^{-1}$ in 2017 and 2019, respectively, which was double the standard value, indicating poor air tightness in this residence.

Table 3. Air change rate $(\mathrm{ACH})$ in the measured living rooms.

\begin{tabular}{cccccc}
\hline $\mathbf{2 0 1 7}$ & $\mathbf{A C H}\left[\mathbf{h}^{-\mathbf{1}}\right]$ & $\begin{array}{c}\mathbf{C O}_{2} \text { Average Concentration } \\
\text { at Night [ppm] }\end{array}$ & $\mathbf{2 0 1 9}$ & $\mathbf{A C H}\left[\mathbf{h}^{-1}\right]$ & $\begin{array}{c}\mathbf{C O}_{2} \text { Average Concentration } \\
\text { at Night [ppm] }\end{array}$ \\
\hline R1 & 0.57 & 1191 & Q1 & 0.67 & 983 \\
R2 & 1.62 & 677 & Q2 & 1.74 & 585 \\
R3 & 0.34 & 1702 & Q3 & - & 1606 \\
R4 & 0.37 & 1272 & Q4 & 0.25 & 2338 \\
R5 & 0.2 & 3080 & Q5 & 0.27 & 853 \\
R6 & 0.62 & 666 & Q6 & 0.52 & 1153 \\
R7 & 0.48 & 2024 & Q7 & 0.15 & \\
R8 & 2.2 & 665 & & 0.89 & \\
R9 & 0.51 & 1198 & & & 1419 \\
R10 & 0.89 & 1190 & Average & 0.64 & \\
Average & 0.78 & 1367 &
\end{tabular}


(2) Air-tightness detector results

Table 4 presents the overall residential air tightness. The range of $\mathrm{ACH}$ under natural conditions was $0.40-1.49 \mathrm{~h}^{-1}$, whereas the range of $\mathrm{ACH}$ under standard conditions was $6.86-25.37 \mathrm{~h}^{-1}$. Chen reported that the standard air-tightness $\left(\mathrm{ACH}_{50}\right)$ values of urban dwellings built in the 1980s and 1990s in Beijing and Tangshan, both cold regions of China, were $4.08 \mathrm{~h}^{-1}$ and $16.7 \mathrm{~h}^{-1}$, respectively [32]. Generally, the requirements of residential air tightness are higher in severe cold climate zones; however, the air tightness of the five households of this study was worse than that of Beijing urban houses.

Table 4. Air change rate of the entire residence.

\begin{tabular}{ccccccc}
\hline & Q2 & Q4 & Q6 & Q7 & Q8 & Average \pm SD \\
\hline Gap area $\left[\mathrm{cm}^{2}\right]$ & 848 & 319 & 206 & 319 & 492 & $436 \pm 252$ \\
Pressure index & 0.45 & 0.64 & 0.59 & 0.58 & 0.64 & $0.58 \pm 0.08$ \\
$\mathrm{ACH}_{50}\left[\mathrm{~h}^{-1}\right]$ & 25.37 & 7.58 & 6.86 & 7.33 & 16.58 & $12.74 \pm 8.14$ \\
$\mathrm{ACH}\left[\mathrm{h}^{-1}\right]$ & 1.49 & 0.45 & 0.4 & 0.43 & 0.98 & $0.75 \pm 0.48$ \\
Airflow $\left[\mathrm{m}^{3} / \mathrm{h}\right]$ & 2771 & 1032 & 639 & 1033 & 1526 & $1400 \pm 828$ \\
\hline
\end{tabular}

Figure 9 is the fitting curve of the pressure difference and airflow of the five households. Under the same pressure difference conditions, the airflow in the different houses varies substantially. Q2 had the largest air leakage followed by Q8. Under standard conditions, Q2 had a maximum air leakage of $2771 \mathrm{~m}^{3} / \mathrm{h}$ and an indoor $\mathrm{ACH}$ of $1.49 \mathrm{~h}^{-1}$, which was much larger than that for the other four households. Thus, different rural houses in the study area exhibited variable air-tightness performance. Residences with poor air-tightness had a large airflow, which reflects large defects in the thermal performance of the residential envelope structure.

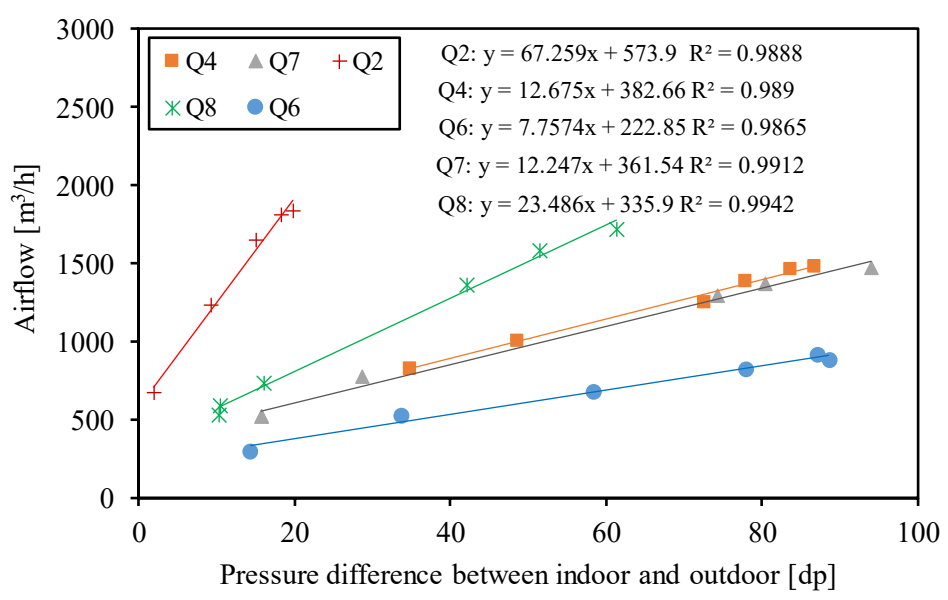

Figure 9. Fitting curve of the pressure difference between the indoor and the outdoor areas and the airflow.

The correlation between the quantitative results of the $\mathrm{CO}_{2}$ generation method and the decompression method measurement results is shown in Figure 10. A significant correlation was observed $(p=0.008)$, indicating that the quantitative $\mathrm{CO}_{2}$ generation method can accurately reflect the residential $\mathrm{ACH}$. 


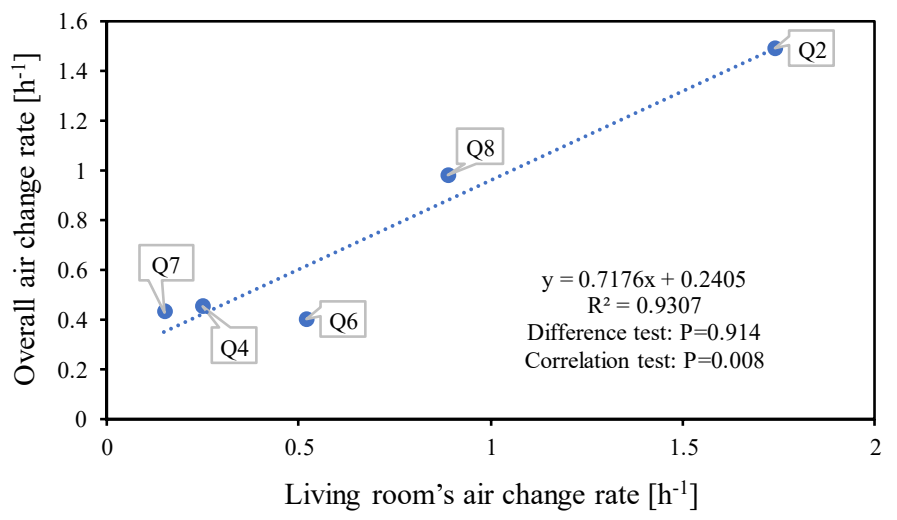

Figure 10. Relationship between the overall $\mathrm{ACH}$ (measured by the decompression method) and the living room $\mathrm{ACH}$ (calculated by the $\mathrm{CO}_{2}$ gas tracer method).

\subsubsection{Thermal Defects of the Residential Envelope}

This study revealed that the air tightness of some households was poor, which indicates that there might be air leakage from the doors and windows of these households. IRT technology can intuitively detect the specific air leakage position of the doors and windows. Figure 11 shows the thermal defects in the residential envelope obtained by IRT. Air leakage was found from the doors and windows of eight households, at the openable area of the windows. In addition, the thermal bridge phenomenon was observed at the corners of the walls of Q3, Q7 and Q8, and condensation occurred on the walls in Q7.
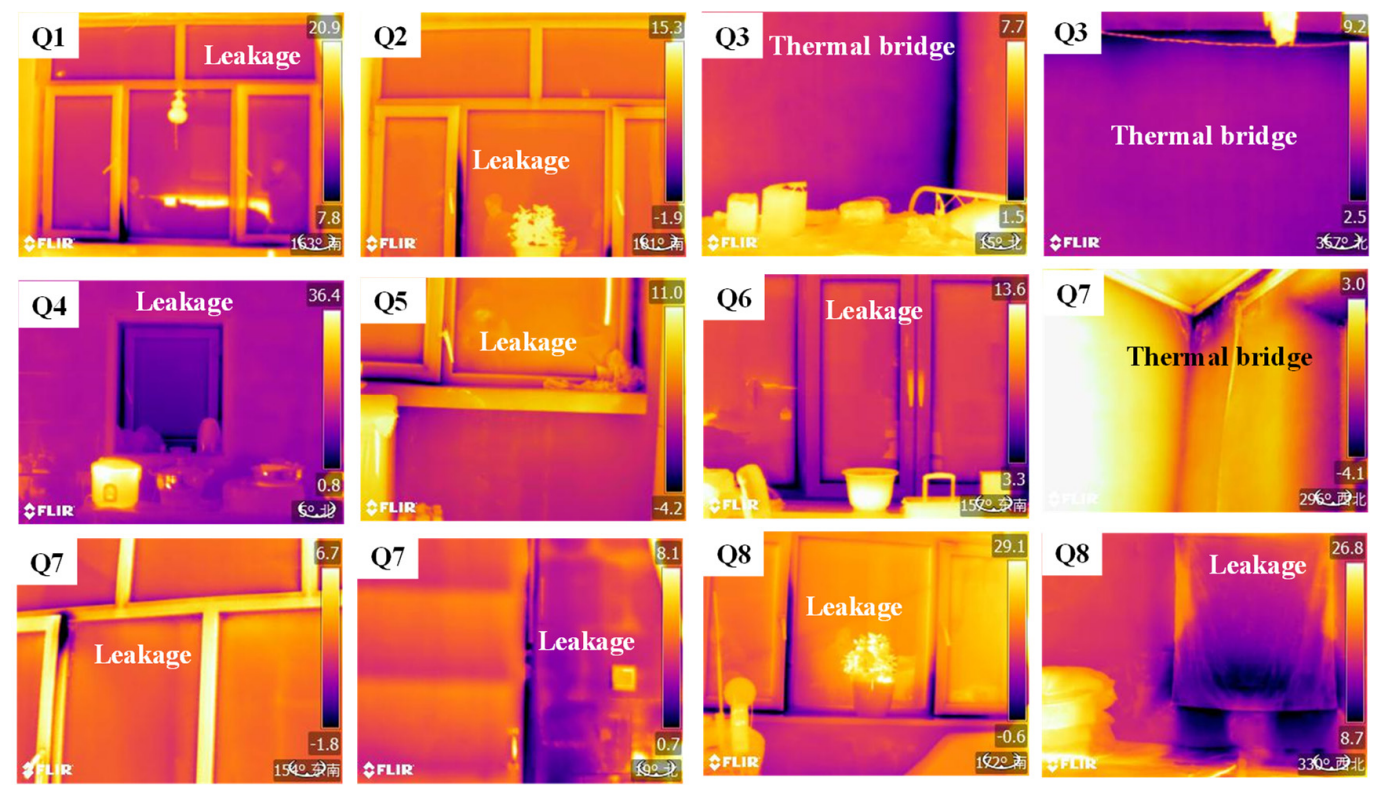

Figure 11. Thermal defects of the residential envelope.

\subsubsection{Heat Transfer Coefficient of the Residential Exterior Walls}

The method for quantitatively analyzing the heat transfer coefficient of the buildings' exterior walls by infrared thermal imaging technology is as follows:

$$
\mathrm{U}=\frac{\varepsilon_{\text {wall }} * \sigma *\left(\mathrm{~T}_{\text {ref }}^{4}-\mathrm{T}_{\text {wall }}^{4}\right)+h_{\mathrm{c}} *\left(\mathrm{~T}_{\text {in }}-\mathrm{T}_{\text {wall }}\right)}{\mathrm{T}_{\text {in }}-\mathrm{T}_{\text {out }}}
$$


where $\mathrm{U}$ is the heat transfer coefficient $\left(\mathrm{W} /\left(\mathrm{m}^{2} \cdot \mathrm{K}\right)\right) ; \varepsilon_{\text {wall }}$ is the emissivity $(0<\varepsilon<1$, which depends on the wall material and the surface temperature and was set to $\varepsilon=0.95$ in this study [25]); $\sigma$ is the Stefan Boltzmann constant: $5.67 \times 10^{-8} \mathrm{~W} /\left(\mathrm{m}^{2} \mathrm{~K}^{4}\right) ; T_{\text {ref }}$ is the reference temperature $\left({ }^{\circ} \mathrm{C}\right) ; T_{\text {wall }}$ is the wall surface temperature $\left({ }^{\circ} \mathrm{C}\right) ; h_{c}$ is the convection heat transfer coefficient $\left(\mathrm{W} /\left(\mathrm{m}^{2} \cdot \mathrm{K}\right)\right)(\mathrm{ISO} 9869-1: 2014$ specifies that the heat transfer coefficient of a building surface is $2.5 \mathrm{~W} / \mathrm{m}^{2} \cdot \mathrm{K}$, which was adopted in this study) [33]; $T_{\text {in }}$ is the indoor air temperature $\left({ }^{\circ} \mathrm{C}\right)$; and $T_{\text {out }}$ is the outdoor air temperature $\left({ }^{\circ} \mathrm{C}\right)$.

Thermal bridging can influence the test results and calculation results of the heat transfer coefficient of the external walls; thus, the locations of the measurement point and the thermal bridge need to be considered. Studies have shown that, when the distance between the measuring point and the position of the thermal bridge exceeds $50 \mathrm{~cm}$, the test results of the wall heat transfer coefficient are approximately stable [34]. Considering the many uncontrollable factors in the measurement process, the location of the measurement point was selected at as great a distance over $50 \mathrm{~cm}$ from the thermal bridge as possible. Therefore, the areas shown in Figure 12 were selected as the representative wall surfaces because they excluded windows and other objects; the average wall surface temperature within each area was used to calculate the heat transfer coefficient of the external walls.
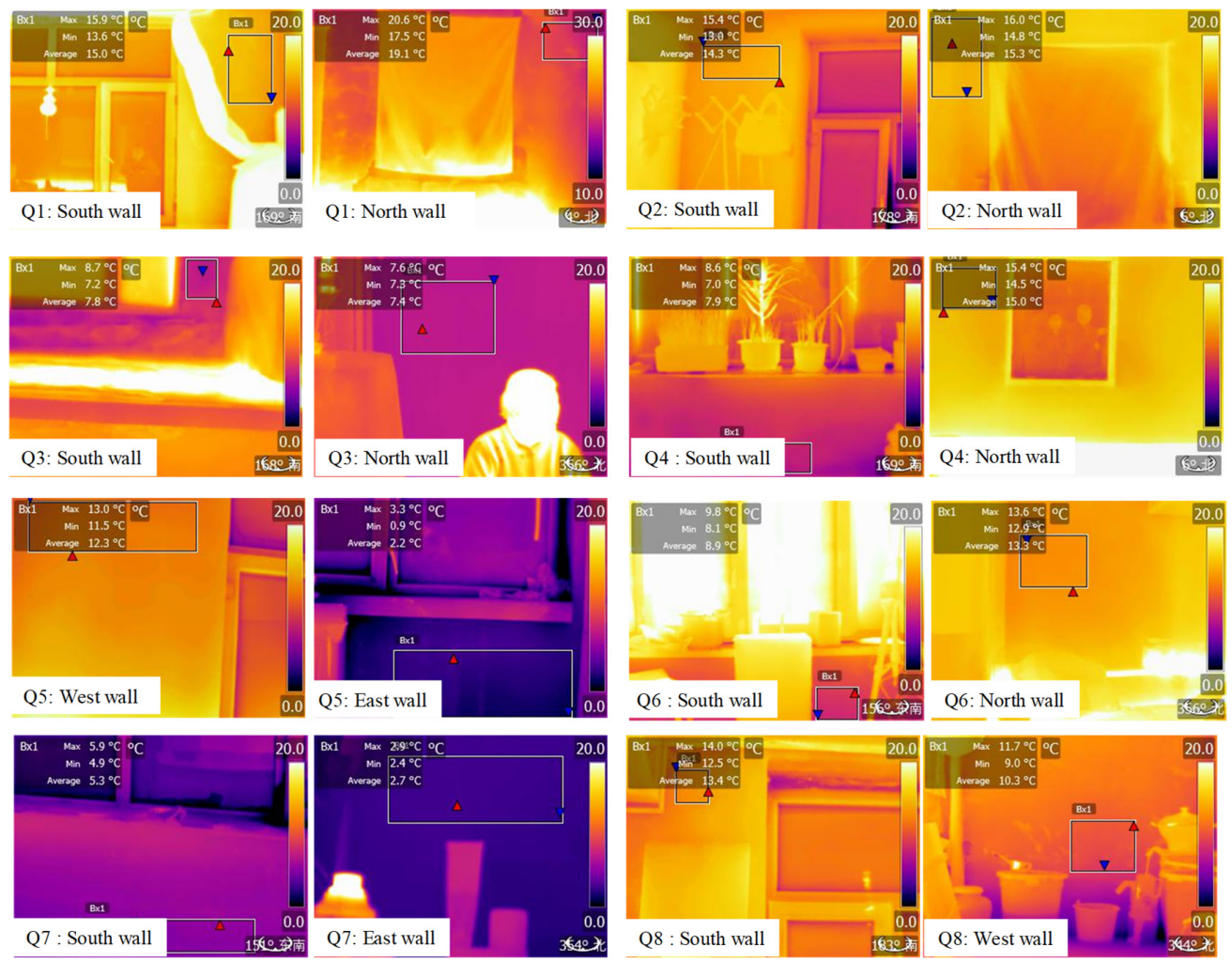

Figure 12. Location of the measurement points for determining the heat transfer coefficient of the external walls.

Among the eight households, the orientation of Q5 was east-west, whereas the other residences were oriented north-south. The window-to-wall ratio of the south-facing residences was $0.22-0.57$, and the window-to-wall ratio of the other external walls of the living room was 0-0.10. Except for the south wall, all the other external walls had the same thickness and the window-to-wall ratio was small. Table 5 shows the overall heat transfer coefficient of the external walls. The heat transfer coefficient of the external wall ranged from $0.25-0.74 \mathrm{~W} /\left(\mathrm{m}^{2} \cdot \mathrm{K}\right)$, with an average value of $0.44 \mathrm{~W} /\left(\mathrm{m}^{2} \cdot \mathrm{K}\right)$. The Chinese energy-saving design standard JGJ 26-2018 limit for the heat transfer coefficient was $0.25 \mathrm{~W} /\left(\mathrm{m}^{2} \cdot \mathrm{K}\right)$ in this area [35]. The heat transfer coefficient of external walls with a window-to-wall ratio of $0.22-0.57$ was $0.33-0.78 \mathrm{~W} /\left(\mathrm{m}^{2} \cdot \mathrm{K}\right)$, with an average value of $0.53 \mathrm{~W} /\left(\mathrm{m}^{2} \cdot \mathrm{K}\right)$. Conversely, the heat 
transfer coefficient of the external walls with a window-to-wall ratio of $0-0.10$ was $0.16-0.69 \mathrm{~W} /\left(\mathrm{m}^{2} \cdot \mathrm{K}\right)$, with an average value of $0.33 \mathrm{~W} /\left(\mathrm{m}^{2} \cdot \mathrm{K}\right)$.

Table 5. Overall heat transfer coefficients of the residential exterior walls.

\begin{tabular}{|c|c|c|c|c|c|c|c|c|}
\hline & & $\begin{array}{c}\text { Area Ratio of } \\
\text { Window to Wall }\end{array}$ & $\begin{array}{l}\mathrm{T}_{\text {ref }} \\
{\left[{ }^{\circ} \mathrm{C}\right]}\end{array}$ & $\begin{array}{l}\mathrm{T}_{\text {wall }} \\
{\left[{ }^{\circ} \mathrm{C}\right]}\end{array}$ & $\begin{array}{c}\mathrm{T}_{\mathrm{in}} \\
{\left[{ }^{\circ} \mathrm{C}\right]}\end{array}$ & $\begin{array}{l}\mathrm{T}_{\text {out }} \\
{\left[{ }^{\circ} \mathrm{C}\right]}\end{array}$ & $\begin{array}{c}\mathrm{U} \\
{\left[\mathrm{W} /\left(\mathrm{m}^{2} \cdot \mathrm{K}\right)\right]}\end{array}$ & $\begin{array}{l}\text { Average U } \\
{\left[\mathrm{W} /\left(\mathrm{m}^{2} \cdot \mathrm{K}\right)\right]}\end{array}$ \\
\hline \multirow{2}{*}{ Q1 } & South wall & 0.38 & 18.6 & 15 & 18.6 & -12.2 & 0.33 & \multirow{2}{*}{0.25} \\
\hline & North wall & 0.1 & 20 & 18 & 20 & -11.5 & 0.16 & \\
\hline \multirow{2}{*}{ Q2 } & South wall & 0.35 & 18 & 14.3 & 18 & -6.4 & 0.5 & \multirow{2}{*}{0.39} \\
\hline & North wall & 0.11 & 18 & 15.3 & 18 & -6.4 & 0.29 & \\
\hline \multirow{2}{*}{ Q3 } & South wall & 0.57 & 12.5 & 7.8 & 12.5 & -5.1 & 0.66 & \multirow{2}{*}{0.58} \\
\hline & North wall & 0 & 11.5 & 7.4 & 11.5 & -9.6 & 0.49 & \\
\hline \multirow{2}{*}{ Q4 } & South wall & 0.43 & 16.5 & 7.5 & 16.5 & -10.7 & 0.57 & \multirow{2}{*}{0.33} \\
\hline & North wall & 0.09 & 15.9 & 15 & 15.9 & -12.9 & 0.08 & \\
\hline \multirow{2}{*}{ Q5 } & West wall & 0.22 & 16 & 13.1 & 16 & -16.9 & 0.35 & \multirow{2}{*}{0.32} \\
\hline & East wall & 0 & 16 & 12.3 & 16 & -16.9 & 0.28 & \\
\hline \multirow{2}{*}{ Q6 } & South wall & 0.48 & 18.2 & 8.9 & 18.2 & -11.7 & 0.69 & \multirow{2}{*}{0.52} \\
\hline & North wall & 0 & 16.4 & 13.3 & 16.4 & -11.8 & 0.34 & \\
\hline \multirow{2}{*}{ Q7 } & South wall & 0.55 & 11.6 & 5.3 & 11.6 & -10.4 & 0.78 & \multirow{2}{*}{0.74} \\
\hline & East wall & 0 & 7.7 & 2.7 & 7.7 & -10.4 & 0.69 & \\
\hline \multirow{2}{*}{ Q8 } & South wall & 0.39 & 17.1 & 13.5 & 17.1 & -6.6 & 0.38 & \multirow{2}{*}{0.36} \\
\hline & West wall & 0 & 13.6 & 10.3 & 13.6 & -10.5 & 0.34 & \\
\hline
\end{tabular}

Generally, the building envelopes of the local residential structures are composed of double-glass windows and 350-600 mm brick walls; the thermal performance of the windows was poorer than that of the brick walls. Therefore, the larger the window-to-wall ratio of the external wall, the higher the overall heat transfer coefficient, which results in higher residential heating energy consumption. JGJ 26-2018 stipulates that the window-to-wall ratio of the south wall of the residential buildings in severe cold areas should be 0.45 . In this study, the south-wall window-to-wall ratio was higher than this limit in three residential houses. Figure 13 shows a significant positive correlation between the window-to-wall ratio of the south wall and the heat transfer coefficient of the south wall. According to this correlation, if the window-to-wall ratio is 0.45 , the heat transfer coefficient of the outer wall of the south wall is $0.56 \mathrm{~W} /\left(\mathrm{m}^{2} \cdot \mathrm{K}\right)$, which is higher than the standard.

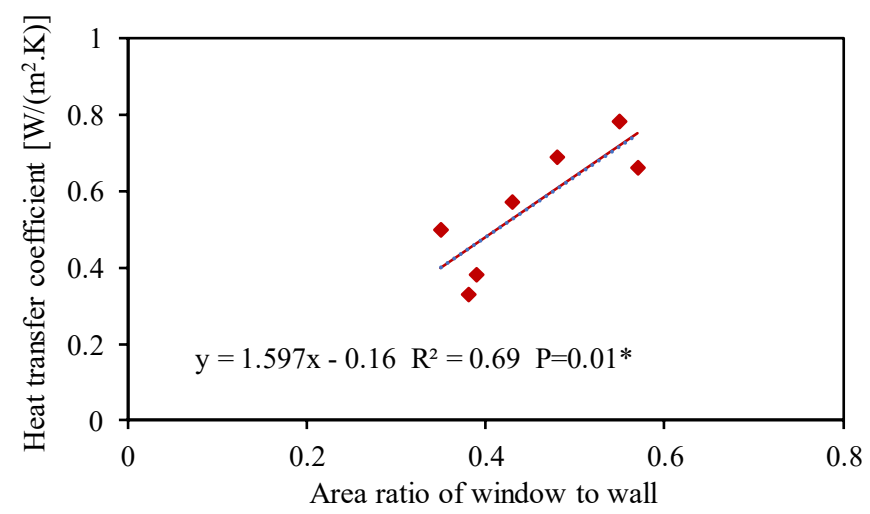

Figure 13. Relationship between the window-to-wall ratio and the heat transfer coefficient of the external walls in the living rooms of elderly housing. 


\subsection{Relationship between Thermal Performance of the Residential Envelope and Indoor Thermal Environment}

\subsubsection{Relationship between the Heat Transfer Coefficient of Exterior Walls and Indoor Temperature}

Figure 14 illustrates the relationship between the external wall heat transfer coefficient and the average indoor temperature. The higher the external wall heat transfer coefficient, the lower the indoor temperature. By substituting the thermal neutral temperature of $17.32{ }^{\circ} \mathrm{C}$ with the average linear regression equation shown in Figure 14, the comprehensive heat transfer coefficient of the outer wall becomes $0.26 \mathrm{~W} /\left(\mathrm{m}^{2} \cdot \mathrm{K}\right)$, which is close to the requirements of JGJ 26-2018 for the heat transfer coefficient of the residential outer walls in this area $\left(0.25 \mathrm{~W} /\left(\mathrm{m}^{2} \cdot \mathrm{K}\right)\right)$ [35]. Due to the limited sample size, this study did not observe a significant correlation between the comprehensive heat transfer coefficient of the external wall and the indoor air temperature. Moreover, the indoor air temperature depends on not only the heat transfer coefficient of the wall, but also the indoor heating intensity. Subsequent studies with a larger sample size and quantitative heating intensity measurements are required to improve these findings.

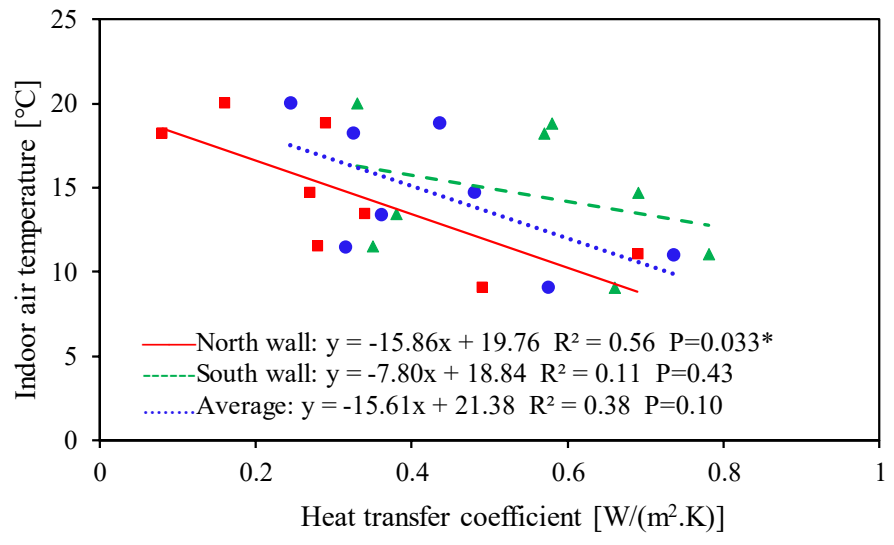

Figure 14. Relationship between the heat transfer coefficient of the external walls and the indoor air temperature.

\subsubsection{Relationship between the Comprehensive Building Thermal Performance and Indoor Temperature}

The results showed that the average temperature of the living rooms of Q1, Q2 and Q4 reached the thermal neutral temperature in 2019. Figure 15 presents a comprehensive analysis of the relationship between the indoor average temperature and the thermal performance of the housing envelope. For all the households, the $\mathrm{ACH}$ and the heat transfer coefficient of the external walls exceeded the limits of the GB/T 50736-2012 and the JGJ 26-2008, respectively. Among them, the ACH and external wall heat transfer coefficient values for Q1, Q4 and Q8 were within the standard value, and the average indoor temperature was greater than the thermal neutral temperature $\left(17.32^{\circ} \mathrm{C}\right)$. The ACH of Q3, Q6 and Q7 was double that of the standard value, and the average indoor temperature was less than the thermal neutral temperature.

The thermal performance of residential building envelopes is not the only factor affecting the indoor thermal environment. First, the external wall heat transfer coefficient and the ACH of Q5 were similar to those of Q4, but the indoor temperature was $7{ }^{\circ} \mathrm{C}$ lower than that of Q4. This is because the heating equipment was improved in Q4, which doubled the indoor temperature. For Q2, the $\mathrm{ACH}$ was more than twice the standard limit; however, the indoor temperature exceeded the thermal neutral temperature. In addition to the low-heat transfer coefficient and high heating intensity of the external walls of Q2, the residence was heated all day, using 22,200 kg of coal. In addition, the Q3 house only employed a "Chinese Kang" as a heating device; therefore, although the external wall heat transfer coefficient of Q3 was lower than that of Q7, the indoor temperature was still lower. Consequently, although the thermal performance of the residential envelope structure is an important 
factor for maintaining a good indoor thermal environment, residents with a poor thermal performance of the envelope structure can maintain a good indoor thermal environment by managing their heating equipment and heating intensity.

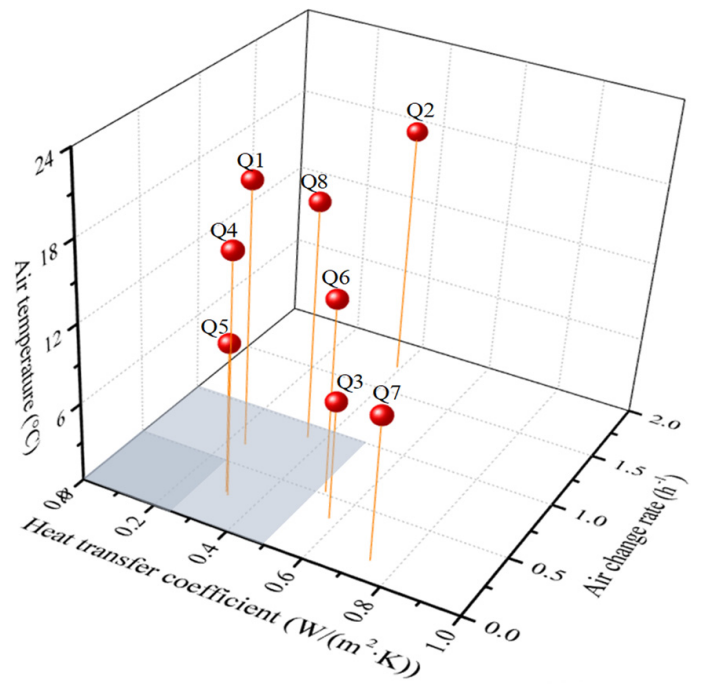

Figure 15. Comprehensive analysis of the air temperature, the heat transfer coefficient of the external walls and the $\mathrm{ACH}$ in the living rooms of elderly housing.

\section{Conclusions}

This study conducted a thorough analysis of the indoor thermal environment and thermal performance of residential envelope structures in rural elderly housing in the severe cold region of Qiqihar. The following conclusions were drawn:

(1) The indoor thermal environment of the different residences exhibited clear differences. First, the average living room temperatures in more than $50 \%$ of the residences were lower than the thermal neutral temperature for the elderly $\left(17.32^{\circ} \mathrm{C}\right)$. Second, the orientation of the windows and the heat intensity of the heating equipment affected the relationship between the indoor MRT and the air temperature. The indoor MRT of a house with a west-facing outer window was $1.4^{\circ} \mathrm{C}$ below the air temperature throughout the day. The indoor MRT of a dwelling with a higher effective heat radiation surface was $0.6^{\circ} \mathrm{C}$ higher than the air temperature over a $24 \mathrm{~h}$ period. Finally, the indoor thermal environment varied substantially during the day, with the daytime PMV fluctuating by 2 to 4 units.

(2) The $\mathrm{CO}_{2}$ gas tracer method used to calculate the living room ACH showed that, in 2017 and 2019, the ACH was $0.20-2.20 \mathrm{~h}^{-1}$ and $0.15-1.74 \mathrm{~h}^{-1}$ and residences with an ACH above $0.5 \mathrm{~h}^{-1}$ accounted for $60 \%$ and $58 \%$, respectively. The $\mathrm{ACH}$ for the entire house, detected by the air-tightness detector, ranged from $0.40-1.49 \mathrm{~h}^{-1}$. There was a significant positive correlation between the ACH calculated by these two methods.

(3) Thermal defects were found on the residential envelope structures, and all the residential windows exhibited clear air leakage. The heat transfer coefficient of the external walls of the house ranged from $0.25-0.74 \mathrm{~W} /\left(\mathrm{m}^{2} \cdot \mathrm{K}\right)$. The average heat transfer coefficient of the external wall with the largest window-to-wall ratio was $0.53 \mathrm{~W} /\left(\mathrm{m}^{2} \cdot \mathrm{K}\right)$, which was significantly higher than that of external walls with a window-to-wall ratio of $0-0.10\left(0.33 \mathrm{~W} /\left(\mathrm{m}^{2} \cdot \mathrm{K}\right)\right)$. The heat transfer coefficient of the south wall exhibited a significant positive correlation with the window-to-wall ratio.

(4) A correlation was observed between the thermal performance of the residential envelope and the thermal environment, which indicates that improving the performance of heating equipment and the heating intensity of residences can maintain a comfortable thermal environment in residences with a poor thermal performance of the envelope structure. First, a slight negative correlation was observed between the heat transfer coefficient of the external wall and the indoor temperature. Second, the 
expansion of a flammable flue gas channel doubled the indoor temperature in one residence. Finally, for a house with a ventilation rate of $1.74 \mathrm{~h}^{-1}$ and continuous heating throughout the day, the indoor temperature could exceed the thermal neutral temperature.

This study evaluated the thermal environment of rural elderly housing in a severe cold region of China, then explored the objective factors affecting the thermal environment of residential houses. The first-hand measured data presented in this study reveal the thermal performance of the envelope structure and can be used to improve the thermal environment of rural houses in cold regions in China.

Author Contributions: Conceptualization, H.Z. and Y.C.; methodology, H.Z. and Y.C.; software, Y.C.; formal analysis, Y.C.; investigation, H.Z., Y.C., Z.M., J.R., J.Z.; resources, H.Z., H.Y., J.X. and J.Z.; data curation, H.Z. and Y.C.; writing-original draft preparation, H.Z. and Y.C.; writing-review and editing, H.Z., H.Y. and J.X; visualization, H.Z. and Y.C.; supervision, H.Z.; project administration, H.Z.; funding acquisition, H.Z. and J.Z. All authors have read and agreed to the published version of the manuscript.

Funding: This research project was funded by the National Natural Science Foundation of China (NSFC), grant number 51778358.

Acknowledgments: The authors would like to express deep gratitude to the elderly individuals involved in this study for their substantial cooperation.

Conflicts of Interest: The authors declare no conflict of interest.

\section{Nomenclature}

The following nomenclature is used in this manuscript:

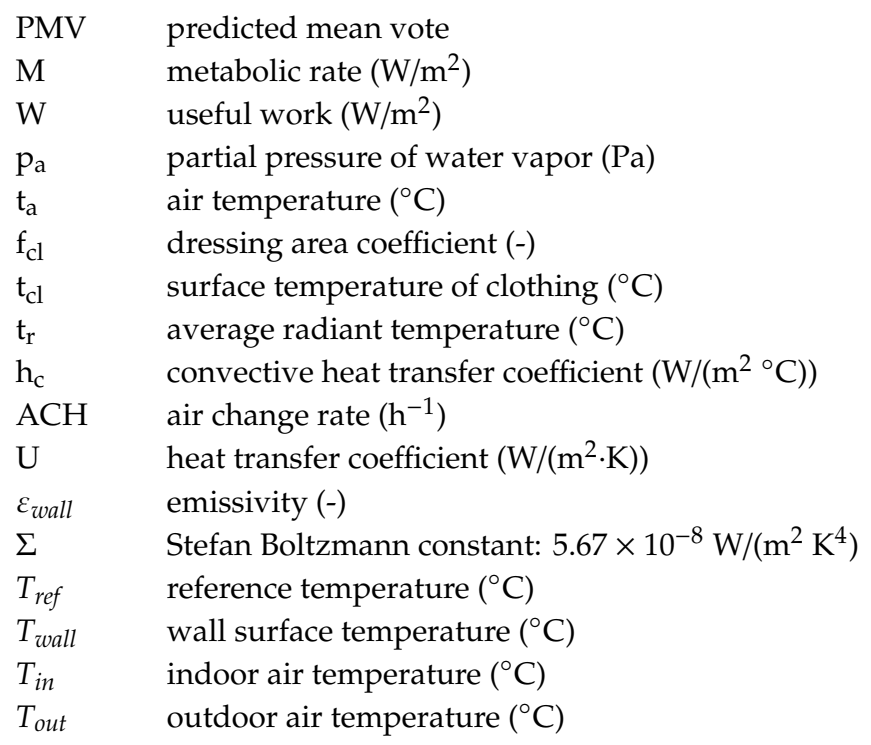

\section{References}

1. Shi, L. China's Urbanization Rate has Risen Sharply in the Past 70 Years, According to a Report Released by the National Bureau of Statistics. Available online: http://www.gov.cn/shuju/2019-08/16/content_5421576.htm (accessed on 16 August 2019).

2. Peng, X.; Shi, Q. Structure change of rural population and employment choice in China. J. Chang'an Univ. (Soc. Sci. Ed.) 2018, 73, 89-98. (In Chinese)

3. Zhuang, Z.; Li, Y.; Chen, B.; Guo, J. Chinese kang as a domestic heating system in rural northern China-A review. Energy Build. 2009, 41, 111-119. [CrossRef]

4. Lin, D.; Zhao, Y.; Wang, Z.S.; Shu, H.W.; Zhu, J.L.; Shan, N.H. Research and assessment method of thermal performance of Chinese kang. Build. Sci. 2009, 25, 28-31.

5. Zhang, H.; Chen, Y.; Rui, J.; Yoshino, H.; Zhang, J.; Chen, X.; Liu, J. Effects of thermal environment on elderly in urban and rural houses during heating season in a severe cold region of China. Energy Build. 2019, 198, 61-74. [CrossRef] 
6. Kyselý, J.; Pokorna, L.; Kyncl, J.; Křiž, B. Excess cardiovascular mortality associated with cold spells in the Czech Republic. BMC Public Health 2009, 9, 19. [CrossRef]

7. Cagle, A.; Hubbard, R.A. Cold-related cardiac mortality in king county, Washington, USA 1980-2001. Ann. Hum. Boil. 2005, 32, 525-537. [CrossRef]

8. Gómez-Acebo, I.; Llorca, J.; Dierssen, T. Cold-related mortality due to cardiovascular diseases, respiratory diseases and cancer: A case-crossover study. Public Health 2013, 127, 252-258. [CrossRef]

9. Ma, L.; Shao, N.; Zhang, J.; Zhang, T.; Xu, M. A study on indoor thermal environment of rural residence in south Liaoning Province. Procedia Eng. 2016, 146, 366-374. [CrossRef]

10. Fan, G.; Xie, J.; Yoshino, H.; Yanagi, U.; Hasegawa, K.; Kagi, N.; Goto, T.; Zhang, Q.; Wang, C.; Liu, J. Yoshino, Indoor environmental conditions in urban and rural homes with older people during heating season: A case in cold region, China. Energy Build. 2018, 167, 334-346. [CrossRef]

11. Building Energy Conservation Research Center, TU. Chinese Residential Energy Annual Development Report in 2013; China Architecture and Building Press: Beijing, China, 2013. (In Chinese)

12. Building Energy Conservation Research Center, TU. China Building Energy Efficiency Annual Development Report in 2012; China Architecture and Building Press: Beijing, China, 2012. (In Chinese)

13. Shao, N.; Zhang, J.; Ma, L. Analysis on indoor thermal environment and optimization on design parameters of rural residence. J. Build. Eng. 2017, 12, 229-238. [CrossRef]

14. Zhu, X.; Liu, J.; Yang, L.; Hu, R. Energy performance of a new Yao Dong dwelling, in the Loess Plateau of China. Energy Build. 2014, 70, 159-166. [CrossRef]

15. Li, Z.; Liu, Z. Energy Efficiency and Indoor Thermal Comfort of rural residential Buildings in Western Liaoning Providence. Build. Energy Effic. 2018, 46, 134-139. (In Chinese)

16. Fanger, P.O. Thermal Comfort; Danish Technical Press: Copenhagen, Denmark, 1970.

17. ISO 7730. Ergonomics of the Thermal Environment: Analytical Determination and Interpretation of Thermal Comfort Using Calculation of the PMV and PPD Indices and Local Thermal Comfort Criteria; International Organization for Standardization: Geneva, Switzerland, 2005.

18. DB11 T555-2015. On-Site Inspection Standards for Civil Building Energy-Saving Projects; Beijing Municipal Commission of Housing and Urban-Rural Development: Beijing, China, 2015. (In Chinese)

19. E779-03. ASTM Method for Determining Air Leakage Rates by Fan Pressurization Test; ASTM International: West Conshohocken, PA, USA, 2013.

20. Fox, M.; Goodhew, S.; De Wilde, P. Building defect detection: External versus internal thermography. Build. Environ. 2016, 105, 317-331. [CrossRef]

21. Kirimtat, A.; Krejcar, O. A review of infrared thermography for the investigation of building envelopes: Advances and prospects. Energy Build. 2018, 176, 390-406. [CrossRef]

22. O'Grady, M.; Lechowska, A.; Harte, A.M. Harte, Quantification of heat losses through building envelope thermal bridges influenced by wind velocity using the outdoor infrared thermography technique. Appl. Energy 2017, 208, 1038-1052. [CrossRef]

23. Herrán, B.T.; Casals, M.; Gangolells, M.; Roca-Ramon, X. Quantitative internal infrared thermography for determining in-situ thermal behaviour of façades. Energy Build. 2017, 151, 187-197.

24. Lu, X.; Memari, A. Application of infrared thermography for in-situ determination of building envelope thermal properties. J. Build. Eng. 2019, 26, 100885. [CrossRef]

25. ISO 10878. Non-Destructive Testing_Infrared Thermography_Vocabulary; International Organization for Standardization: Geneva, Switzerland, 2013.

26. Chen, Y.; Zhang, H.; Yoshino, H.; Xie, J.; Yanagi, U.; Hasegawa, K.; Kagi, N.; Goto, T.; Zhang, Q.; Zhang, J. Winter indoor environment of elderly households: A case of rural regions in northeast and southeast China. Build. Environ. 2019, 165, 106388. [CrossRef]

27. GB/T 18883-2002. Indoor Air Quality Standard; Ministry of Environmental Protection of the People's Republic of China: Beijing, China, 2002. (In Chinese)

28. Sheng, X. Field Test and Analysis of Thermal Comfort at Rural Houses and Urban Residential Buildings in Severe Cold Region. Master's Thesis. Harbin Institute of Technology, Harbin, China, 2013. (In Chinese).

29. Roulet, C.A.; Foradini, F. Simple and cheap air change rate measurement using $\mathrm{CO}_{2}$ concentration decays. Int. J. Vent. 2002, 1, 39-44.

30. Cui, S.; Cohen, M.; Stabat, P.; Marchio, D. $\mathrm{CO}_{2}$ tracer gas concentration decay method for measuring air change rate. Build. Environ. 2015, 84, 162-169. [CrossRef] 
31. GB/T 50736-2012. Design Code for Heating Ventilation and Air Conditioning of Civil Buildings; Ministry of Housing and Urban-Rural Development of the People's Republic of China: Beijing, China, 2012. (In Chinese)

32. Chen, S.; Levine, M.D.; Li, H.; Yowargana, P.; Xie, L. Measured air tightness performance of residential buildings in North China and its influence on district space heating energy use. Energy Build. 2012, 51, 157-164. [CrossRef]

33. International Organization for Standardization ISO 9869:2014. Thermal Insulation—Building Elements-In-Situ Measurement of Thermal Resistance and Thermal Transmittance - Part 1: Heat Flow Meter Method; British Standards Institution (BSI): London, UK, 2014.

34. Li, Y.; Li, J.; Zhang, H.; Sun, J. Effects of thermal bridge location on heat transfer coefficient of external wall. Build. Energy Effic. 2016, 301, 76-80. (In Chinese) [CrossRef]

35. JGJ 26-2018. Design Standards for Energy Efficiency of Residential Buildings in Severe Cold and Cold Zones; Ministry of Housing and Urban-Rural Development of the People's Republic of China: Beijing, China, 2018. (In Chinese)

(C) 2020 by the authors. Licensee MDPI, Basel, Switzerland. This article is an open access article distributed under the terms and conditions of the Creative Commons Attribution (CC BY) license (http://creativecommons.org/licenses/by/4.0/). 